\title{
COMPARISON OF CHEMICAL COMPOSITION OF PACKABLE RESIN COMPOSITES BY SCANNING ELECTRON MICROSCOPY
}

\author{
COMPARAÇÃO DA COMPOSIÇÃO QUÍMICA DE RESINAS COMPOSTAS COMPACTÁVEIS \\ ATRAVÉS DE MICROSCOPIA ELETRÔNICA DE VARREDURA
}

Ana Amélia BIANCHI e SILVA ${ }^{1}$, Elaine Bauer VEECK ${ }^{2}$, José Pedro Peixoto de OLIVEIRA ${ }^{1}$, Paulo Henrique Couto SOUZA ${ }^{3}$

1- DDS,MSc, Graduate student (Doctor degree), Department of Radiology, PUCRS.

2- DDS, MSc, PhD, Assistant Professor, Department of Radiology, PUCRS.

3- DDS, MSc, PhD, Assistant Professor, Department of Oral Diagnosis, PUCPR.

Corresponding address: Elaine Bauer Veeck - Av. Cristovão Colombo, 3084, conj 708/709 - 90.560-002 - Porto Alegre - RS

Fone: (0XX 51) 3342-4780 3342-8569 - E-mail: ebveeck@zaz.com.br

Received: July 1, 2004 - Modification: August 23, 2004 - Accepted: September 20, 2004

\begin{abstract}
0

bjectives: the purpose of this study was to compare the chemical composition of four different shades (incisal/extra-light, A2, A3 and B3) of two packable resin composites (SOLITAIRE ${ }^{\circledR}$, and PRODIGY CONDENSABLE ${ }^{\mathrm{TM}}$ ). Methods and Materials: the specimens measured $4 \mathrm{~mm}$ in diameter and $4 \mathrm{~mm}$ in thickness. Five specimens were made for each shade of the materials. They were light cured for 40 seconds at a power of $600 \mathrm{~mW} / \mathrm{cm}^{2}$. Subsequently, the specimens were removed from the plates and ground to powder and then pressed into holes measuring $4 \mathrm{~mm}$ in diameter in a Teflon matrix, using the plates of the same material as base and cover. Specimens were evaluated under SEM with an x-ray detector for the spectroscopic test by energy dispersing. Results: the chemical components found in both materials were practically the same, but in different proportions. Carbon, Oxygen, Aluminum, Silica, Fluoride and Barium were found. Conclusions: the chemical composition of each same material varied according to each shade analyzed .

Uniterms: Packable composite; Spectroscopic test; Composite resins.
\end{abstract}

\section{RESUMO}

bjetivo: comparar a composição química de duas resinas compostas compactáveis (SOLITAIRE® ${ }^{\circledR}$, Kulzer, e PRODIGY CONDENSABLE ${ }^{\mathrm{TM}}$, Kerr) em quatro diferentes cores (incisal/extra-light, A2, A3 e B3). Materiais e método: as amostras foram confeccionadas em placas de acrílico transparente com $4 \mathrm{~mm}$ de espessura. Os materiais foram inseridos e compactados em orifícios de $4 \mathrm{~mm}$ de diâmetro. Para cada cor de cada material foram confeccionadas 5 amostras, as quais foram fotopolimerizadas durante 40 segundos a uma potência de $600 \mathrm{~mW} / \mathrm{cm}^{2}$. Logo após, estas foram removidas das placas e trituradas até apresentarem uma consistência de pó, foram prensadas, para colocação das diferentes cores em nichos de 4mm de diâmetro de uma matriz de Teflon, tendo como base e cobertura duas placas do mesmo material. As amostras foram montadas em stubs para a metalização, ou deposição de íons, sendo suas imagens importadas ao microscópio eletrônico de varredura com detector de raios X, para o teste de espectroscopia por dispersão de energia. Resultado: foram encontrados Carbono, Oxigênio, Alumínio, Sílica, Flúor, e Bário em diferentes proporções nos materiais estudados.Conclusão: a composição química de um mesmo material variou de acordo com a cor analisada e os componentes químicos encontrados foram praticamente os mesmos, mas em diferentes proporções.

Unitermos: Compósito condensável; Teste espectroscópico; Resinas compostas. 


\section{INTRODUCTION}

Several restorative materials have been used in dentistry, but not all of them have remained in use nowadays. These materials are improved by manufacturers as failures are observed. Restorative materials, especially the esthetic ones, still have to be extensively researched and improved. Mechanical and esthetic properties are necessary for restoring function and esthetics with durability.(Hazel, Wenzel, Ariseon ${ }^{6}$, 1995).

It was with the emergence of resin composites, more precisely with the development of a new organic molecule, the bis-GMA, that esthetic restorative materials broadened their clinical use. The novelty of a product that was microscopically bonded with the dental structure, dismissing retentive devices, and at the same time presenting suitable esthetics and function contributed to considering the use of resin composites in posterior teeth. (Anusavice ${ }^{2}$, 1998)

The esthetic treatment is currently the prevailing treatment in view of the increasing demand from patients that seek a dentist for esthetic restorations, in addition to the great number of professionals that strive for conservation of remaining vital dental tissues. This greater demand for esthetic restorations has led the dental market to develop a number of products applicable in both anterior and posterior teeth. (Pensler $\left.{ }^{12}, 1998\right)$

With the technological advance of composites, along with a greater knowledge on their indications, the patients can currently count on an immediate esthetic restorative treatment for posterior teeth. (Porto Neto, Machado ${ }^{13}$, 1999)

Evidently, it is necessary to know if these direct esthetic restorative materials are an acceptable replacement for the dental tissues, not only with respect to esthetics, but also to function, cavity sealing and protection of the dentinpulp complex. (Chung, Greener ${ }^{4}$, 1990; Williams, et al. ${ }^{17}, 1995$ ).

From a modification in the organic portion of the resin composites came the silico-organic composites, which also contain organically modified silicate, i.e. in their organic portion there is an inorganic compound (silicate). It is evident that these composition increases the final inorganic content in the matrix, which determines mechanical properties different from those of conventional matrixes (Nagem Filho $^{11}$, 1999).

Iorio $^{7}$ (1999) reported that resin composites used in anterior teeth should preferably extend the restoration up to the premolar teeth, or to small cavities in molars (conservative preparations). More extensive preparations in posterior teeth must be restored with packable resin composites, since they are more resistant to dental wear and facilitate the reconstruction of the contour and proximal contacts of restorations. Perhaps, in the future, packable composites will completely replace the hybrid and microhybrid resin composites in posterior teeth, as they reduce the time spent on the restoration (because they are packable), present lower polymerization stress, have greater resistance to wear and do not require special techniques for preparation of the proximal contact region.

The clinical use of composites has been increasing since the development of the bis-GMA organic molecule. The product demonstrated the capacity to micromecanicaly adhere to the tooth structure and showed suitable esthetic and function properties to be used in anterior and posterior restorations. (Anusavice ${ }^{2}, 1998$ )

The increasing demand for esthetic treatment and conservation of healthy dental tissue are the main reasons for the development of several new resin composite materials (Pensler ${ }^{12}$, 1998). The dental profession has had a faster and better esthetic treatment to offer to the patients. (Porto Neto, Machado ${ }^{13}$,1999).

Resin composites have been modified in their organic portion. The composition has turned into a silico-organic resin wich have increased the inorganic portion. Therefore, the final composition determinated a material with better mechanical properties (Nagem Filho ${ }^{11}$, 1999).

Iorio $^{7}$ in 1999 stated that composites for anterior teeth should be employed preferable in premolars or small cavities in molars . Larger preparatios in molars required packable resin composites, which are more resistant to wear and facilitated the restoration of contour and proximal contact. This material also may save treatment time and produce lower polymeralization stress.

Modification of any dental material requires testing evaluation of mechanical and physical properties. Anusavice $^{2}$ (1998) stated that the properties of a resin composite, such as compressive and tensile strength, wear resistance, modulus of elasticty, water absortion and coefficient of thermal expantion depend on the amount of particles incorporated and bonding to the organic matrix. Translucency, shade and optical features can be modified by any component added to organic matrix.

Silva ${ }^{14}$ in 2002 found significant differences between the optical density values of different shades of packable resins by a digital imaging software. The digitization method was described as quite sensitive in the detection of subtle differences in the optical density values. In addition, the specimens were $4 \mathrm{~mm}$ thick, which favors the assessment of differences. The author also found differences between the clinical and radiographic behavior in one of the materials: the more tranlucent shade, the highest the optical density.

The average size and distribution of fillers in the organic matrix were studied by Lutereau, et al. ${ }^{8}$, in 2001. They used a laser interferometry to measure the inorganic particles. A variation in the average size of the particles between 1.07 and 7.37 microns was observed. As a conclusion, they stated that the filler particles and their distribution determine the physico-mechanical properties of a composite.

The chemical composition of the filler particles was found to have an effect on the properties of a resin composite in a study by Fortin and Vargas ${ }^{5}$ in 2000. Components such as aluminum, lithium, barium, zinc bohrium and yttrium were in the fillers. Ytterbium fluoride was found to be responsible for the anticariogenic effec of the material.

The goal of this study was to compare the composition of two different packable composite resins: SOLITAIRE ${ }^{\circledR}$ (Heraeus Kulzer, Hanau, Germany) and PRODIGY CONDENSABLE ${ }^{\mathrm{TM}}$ (Kerr, West Collins Orange, USA) in four 
different shades under SEM (Scanning Electron Microscopy).

\section{MATERIALAND METHODS}

Five transparent acrylic plates were used as matrixes for each of two resin materials. They were $5.7 \times 7.1 \mathrm{~cm}$ and $4 \mathrm{~mm}$ thick. Every plate was divided into four quadrants, with a $4 \mathrm{~mm}$ diameter perforation in the center of each, with a groove to establish a venting system to flow the excess material and allow the specimens to have the same thickness .

Every plate was marked to identify every resin and shade. The upper left quadrant was filled with the extra light shade or incisal. In clockwise direction, shades A2, A3 and B3 were packed. Both grooves at the upper edge and the central orifice in the plate were filled with microhybrid resin composite (Figure 1).

All specimens were light-cured with a visible light-curing unit (VIP, Bisco) for 40s, at a 600 $\mathrm{mW} / \mathrm{cm}$ energy. Increments of $2 \mathrm{~mm}$ were used.

The samples were removed from the plates and separated according to the shades and materials in order to be ground (EXT-Tritmat grinder, Phillips). This procedure was applied to improve the chemical assessment.

The specimens were evaluated under SEM (Phillips XL30, Holand) with an X-ray image detector and a secondary

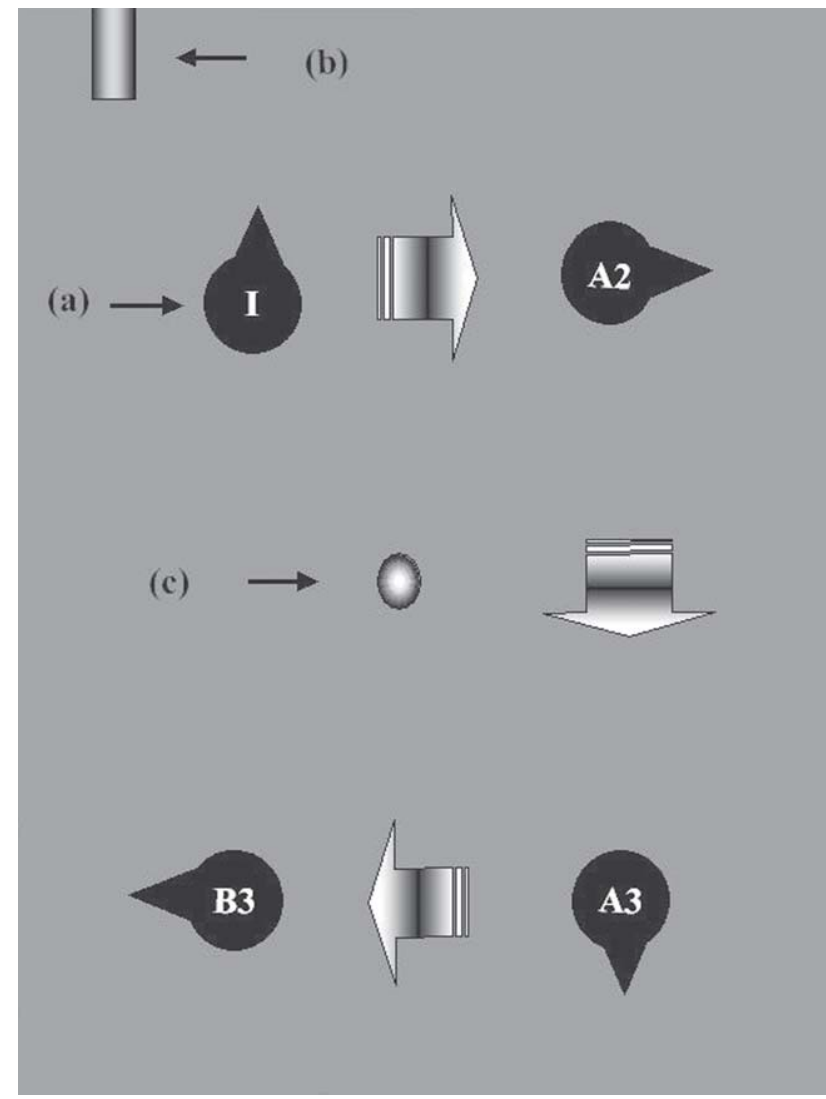

FIGURE 1- Grooves and orifices for placement, identification and escape of materials, a- outlet groove; b- identification groove of the upper left quadrant; c- central orifice for identification of PRODIGY CONDENSABLE ${ }^{\mathrm{TM}}$ resin. electron detector for energy dispersion spectroscopy, or EDS (CDU LEAP-EDA X). After selection of 3 areas in every specimen, the EDS test readings were performed (Figure 2).

\section{RESULTS AND DISCUSSION}

With the emergence of packable resin composites, the indication of direct esthetic materials for posterior teeth became a reality, as they were presented by manufacturers as a replacement for silver amalgam. In spite of this, it was observed, by several clinical and in vitro studies, that composites still need a careful selection of clinical cases in order to be more effective as a restorative material for posterior teeth.

Several products have been released in the dental market, including SOLITAIRE ${ }^{\circledR}$ and PRODIGY CONDENSABLETM, which were analyzed in this study in four different shades, comparing the existent variations in their chemical composition (Table1).

Silva e Souza Jr, Carvalho and Mondelli ${ }^{15}$ (2000) reported that the basic composition of the inorganic filler of resin composite SOLITAIRE ${ }^{\circledR}$ is barium, bohrium and silicate. According to the results of this study, the component bohrium was not found in any specimen, while the others coponents were found in percentages that differ from one shade to another.

As composition of the filler particles influences their properties, their concentration and distribution in the organic matrix do the same. SEM was employed to verify these features. This method is described as quite reliable and practical for this purpose. Fortin and Vargas ${ }^{5}$ (2000) found, by using the same method, several components in resin composite, including: aluminum, lithium, barium, zinc, bohrum, yttrium and ytterbium fluoride. Lithium, zinc, bohrum, yttrium and ytterbium were not found in any specimen from the two materials in this study, whereas there was presence of carbon and oxygen, which were likely to belong to the organic matrix of the materials.

Further methods for determination of the basic composition of the materials were found in literature. Lutereau,

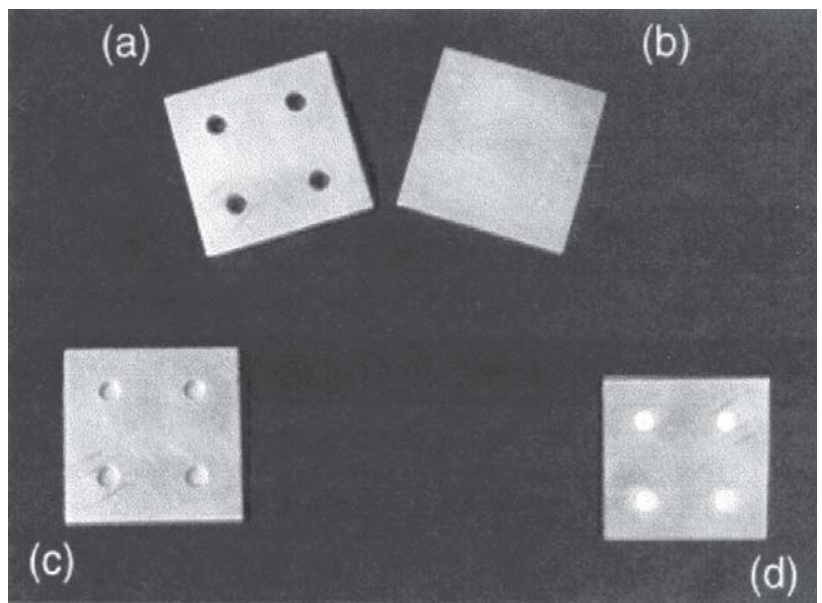

FIGURE 2- Teflon matrix for material pressing. a- matrix with holes; b- Teflon base; c-matrix/base; d-ground SOLITAIRE resin specimens in their respective orifices. 
et al. ${ }^{8}$ (2001) used laser interferometry and concluded that the filler content and its distribution in the organic matrix plays a direct role in the physico-mechanical properties. However, in this study, SEM has proven to be very efficient in the determination of the basic chemical composition of the materials.

PRODIGY CONDENSABLE ${ }^{\mathrm{TM}}$ and SOLITAIRE ${ }^{\circledR}$ resin composites have been described to be superior to conventional resin composites when used in posterior teeth (Muñoz Chavez, et al. ${ }^{10}$, 1999; The Dental Advisor ${ }^{16}$, 1999; Iório $^{7}$, 1999; Silva e Souza Jr. Carvalho and Mondelli15 ${ }^{15}$, 2000). They show gray levels that allow their identification on conventional and digital radiographs, as described by Cardoso, Mallmann ${ }^{3}$ (1999).

According to Silva e Souza Jr, Carvalho and Mondelli ${ }^{15}$ (2000), PRODIGY CONDENSABLETM is comprised by an inorganic filler of glass particles containing barium and siliconoxide. The EDS results obtained in this study reveal that, in addition to these components, every PRODIGY CONDENSABLETM ${ }^{\mathrm{TM}}$ specimen presented aluminum, while the shade A2 showed some amount of fluoride.

Shade A2 was observed to have the lowest fluoride rate (1.14\%) among the SOLITAIRE ${ }^{\circledR}$ specimens. According to Silva ${ }^{14}$ (2002), between the same shades analyzed, SOLITAIRE's A2 was the one with the lowest mean optical density value. According to this study, fluoride may have been responsible for an increase in the radiopacity of the incisal shade of SOLITAIRE ${ }^{\circledR}$. Likewise, the shade described as having the highest radiopacity (SOLITAIRE's shade B3) presented the greatest amount of fluoride ions. Abreu, Tavares, and Vieira, ${ }^{1}(1977)$ reported that addition of fluoride causes an increase in the radiopacity of the material. However, it was not possible to determine statistical differences between the percentage of components. The scanning electron microscopy failed to provide the standard deviation, neither to ascertain whether the differences found in the chemical compositions were as significant as those found in radiopacity studies.

The results of this study are in agreement with the results achieved by Silva ${ }^{14}$ (2002). The aluminum concentration may also have caused an increase in the mean optical density. Regarding the aluminum content, the concentration of this component in the shades of SOLITAIRE was found to vary between the different shades and was proportional to the optical density values. Yoshida, Taira and Atsuta ${ }^{18}$ (2001) found that aluminum is widely employed as pigment in opaque resin composites, in the form of aluminum dioxide. Probably, the great content of aluminum in an incisal shade is to recreate the effect of enamel of the cusps, which is achieved by adding a greater amount of aluminum.

Aluminum dioxide is a component used in the organic matrix of resin composites to act as a pigment. Marouf and Sidhu $^{9}$ (1998) raised the hypothesis that different pigments added to the organic matrix may lead to a variation in radiopacity. Although these authors did not find significant differences with respect to this, maybe because the thickness of the specimens was too thin $(1 \mathrm{~mm})$, the results of this study demonstrate that there is a difference between the chemical compositions in the different shades of the same material, and that this difference results in radiopacity variations between the different shades of the same material.

For the SOLITAIRE ${ }^{\circledR}$ resin, we found that the concentration of barium ions did not interfere with the radiopacity values described by Silva ${ }^{14}$ (2002), since one of the lowest rates of this component was shown by the most radiopaque shade described by the authors, while the highest amount of barium in this material (14.78\%) was the lowest optical density values.

A clinical aspect that migth be pointed out is the indication of SOLITAIRE ${ }^{\circledR}$ incisal shade for the first increments in deep cavities, which are more difficult to be reached by the curing light source, since the material presents a suitable radiopacity that is easier to identify on the margins of cavities, as described by Silva ${ }^{14}(2002)$. Thus, further studies must be conducted in order to determine the degree of conversion of the materials under study, and verify its correlation with the optical density values.

Based on literature and on the results of this study, we believe that the packable composite resins represent a promising new class of direct esthetic restorative materials for posterior teeth. However, further studies on the clinical and radiographic properties of these materials must to be undertaken so that, in the future, they may be regarded as definitive restorative materials.

TABLE 1- Weight percentage of the components of the resins tested: carbon (C), oxygen (O), fluorine (F), aluminum (Al), silica (Si) and barium (Ba)

\begin{tabular}{lllllllll}
\hline & & \multicolumn{3}{c}{ SOLITAIRE $^{\circledR}$} & \multicolumn{5}{c}{ PRODIGY CONDENSABLE } \\
& incisal & A2 & A3 & B3 & extra-light & A2 & A3 & B3 \\
\hline C & 19.91 & 21.35 & 21.25 & 21.44 & 16.28 & 14.30 & 16.27 & 14.27 \\
$\mathrm{O}$ & 29.12 & 30.49 & 32.34 & 33.30 & 30.90 & 23.95 & 28.98 & 22.24 \\
$\mathrm{~F}$ & 2.06 & 1.14 & 2.71 & 2.72 & IIIIIII & 0.14 & IIIIIIII & IIIIIIII \\
$\mathrm{Al}$ & 3.57 & 2.59 & 3.15 & 3.08 & 4.16 & 4.83 & 4.30 & 4.58 \\
$\mathrm{Si}$ & 31.80 & 29.66 & 29.70 & 28.26 & 25.69 & 27.79 & 25.38 & 27.94 \\
$\mathrm{Ba}$ & 13.53 & 14.78 & 10.84 & 11.19 & 22.98 & 28.99 & 25.08 & 30.97 \\
Total & 100.00 & 100.00 & 100.00 & 100.00 & 100.00 & 100.00 & 100.00 & 100.00 \\
\hline
\end{tabular}




\section{CONCLUSION}

1. The different shades of the same resin present similar chemical compositions, but in different concentrations;

2 . The variation in the chemical and structural composition between the different shades of the same material migth be used for choosing a restorative material.

3. The energy dispersion spectroscopy (EDS) was shown to be a very practical and effective method for assessing the chemical composition of the materials.

\section{REFERENCES}

1- Abreu MJN, Tavares D, Vieira DF. Radiopacity of restorative materials. Oper Dent 1977;2(1):3-16.

2- Anusavice KJ. Phillip's Science of Dental Materials. 10.ed. Rio de Janeiro:Guanabara Koogan; 1998.

3- Cardoso PEC, Mallmann A. Resinas compostas condensáveis: uma nova opção restauradora. Dent Gaúcho 1999;6(2):26-30.

4- Chung K, Greener E. Correlation between degree of convertion, filler concentration and mechanical properties of posterior composite resins. J Oral Rehabil, 1990;(17):487-94.

5- Fortin D, Vargas MA. The spectrum of composites: new techniques and materials. J Am Dent 2000;131(6):26-30.

6- Hazel OT, Wenzel A, Ariseon L. Modern dental assisting. 5 ed. Philadelphia: WB Saunders; 1995.

7- Iório PAC. Resinas compostas. Dentística clínica: Adesiva e estética. São Paulo: Santos, 1999.

8- Lutereau SZ, Lutri M, Priotto EG, Echevarria JU. Interferometria LÁSER de la fase inorgânica de sistemas resinosos y compómeros. Rev Odonto Ciênc 2001;16(32):77-83.

9- Marouf N, Sidhu SK. A study on the radiopacity of the different shades of resin-modified glass-ionomer restorative materials. Oper Dent 1998;23(1):10-4.

10- Muñoz Chavez OF, Reis JIL, Santos LM, Andrade MF. Resinas compostas compactáveis. Relato de caso clínico. J Bras Odontol Clín 1999;3(16):11-7.

11- Nagem Filho H. Materiais dentários: resinas compostas. Bauru: Produções Artes Gráficas; 1999.

12- Pensler AV. Shade selection: problems and solutions. Compend Contin Educ Dent 1998; 19(4):387-96.

13- Porto Neto ST, Machado CT. Resinas condensáveis. J Bras Odontol Clín 1999;3(13):35-9.

14- Silva AAB. Resinas compactáveis: densidade óptica e composição química e estrutural através de imagens digitalizadas e microscopia eletrônica. Porto Alegre; 2002. [Dissertação de Mestrado - Faculdade de Odontologia da PUCRS].

15- Silva e Souza Junior MH, Carvalho RM, Mondelli RFL. Odontologia estética. Fundamentos e aplicações clínicas: restaurações com resina composta. São Paulo: Ed. Santos; 2000.

16- The Dental Advisor. Avaliação clínica de resinas compostas compactáveis e convencionais. 1999; 7(10):1-3.
17- Willians G, Cocher S, Webber A, Scarper N. Los composites del siglo XXI. Quintessence 1995; 8(6):351-67.

18- Yoshida K, Taira Y, Atsuta M. Properties of opaque resin composite containing coated and silanized titanium dioxide. J Dent Res 2001; 80(3):864-8. 